\title{
The sound of magic? Bells in Roman Britain
}

Article

Accepted Version

Eckardt, H. and Williams, S. (2018) The sound of magic? Bells in Roman Britain. Britannia, 49. pp. 179-210. ISSN 0068-113X doi: https://doi.org/10.1017/S0068113X18000028 Available at https://centaur.reading.ac.uk/75441/

It is advisable to refer to the publisher's version if you intend to cite from the work. See Guidance on citing.

To link to this article DOI: http://dx.doi.org/10.1017/S0068113X18000028

Publisher: Cambridge University Press

All outputs in CentAUR are protected by Intellectual Property Rights law, including copyright law. Copyright and IPR is retained by the creators or other copyright holders. Terms and conditions for use of this material are defined in the End User Agreement.

\section{www.reading.ac.uk/centaur}

\section{CentAUR}

Central Archive at the University of Reading

Reading's research outputs online 


\title{
The Sound of Magic? Bells in Roman Britain \\ By HELLA ECKARDT and SANDIE WILLIAMS
}

\begin{abstract}
Bells are recorded in many published excavation reports from Roman sites, but there has been no previous study of the British material. This paper explores the significance of bells in the Roman world from both a ritual and functional perspective. We create a first typology of Romano-British bells, provide an understanding of their chronology and examine any spatial and social differences in their use. Special attention is paid to bells from funerary or ritual contexts in order to explore the symbolic significance of these small objects. Bells from other parts of the Roman world are considered to provide comparisons with those from Roman Britain. The paper demonstrates that small bells were used as protective charms and may have been preferentially placed into the graves of children and young women. The paper identifies a new, probably Roman type of bell that has no parallels within the Empire, although similar pieces occur in first-and second-century graves in the Black Sea region.
\end{abstract}

Keywords: Roman bells; amulets; burial; openwork bells; Black Sea

\section{INTRODUCTION}

Many Romano-British sites contain small copper-alloy or iron bells, which on the whole are briefly mentioned in the site reports, illustrated and then forgotten about. The aim of this paper is to consider the function, distribution and symbolic meaning of bells. The paper provides a typology and chronology of the bells, and a greater understanding of their spatial and social distribution. The funerary and ritual evidence in particular are considered in detail. The analysis is based on a corpus of just over 300 bells from Britain, and consideration of some continental examples. Much of this work is based on the second author's MA dissertation. ${ }^{1}$ 
Bells are usually small and the vast majority are cast in copper alloy, with only eight examples made from iron. These figures are likely skewed by the under-recording of iron objects on many sites prior to systematic x-ray analysis and to the bias towards copper-alloy objects recorded on the Portable Antiquities Scheme (PAS). All bells would have originally had a suspension loop at the top, and contained a clapper suspended from the apex of the bell (FIG. 1). There are some examples which appear to have been modified or repaired, including bells which have had a hole drilled into them, possibly in order to replace a clapper or crown staple that had broken. The main form of decoration on Romano-British bells consists of incised grooves around the circumference of the bell; some have small feet on each corner.

There have been numerous theories about the function of the bells, ranging from simple animal bells to apotropaic objects. There is information on Roman bells from written, iconographical and archaeological sources. Bells have been mentioned in Greek and Roman literature from as early as the fifth century B.C., when Aeschylus, in his play 'Seven Against Thebes', describes in detail Tydeus' shield, which contained many bells used to cause terror among his enemies by their sound: 'and at his shield's rim, terror in their tone, clang and reverberate the brazen bells'. ${ }^{2}$ This trick of using bells to frighten an enemy is seen almost 700 years later, as Dio Cassius informs us that a northern British tribe, the Maeatae, had bells attached to the end of their short spears 'so that when it is shaken it may clash and terrify the enemy'. ${ }^{3}$ Bells could also be used to sound a warning; for example, sentries carried bells while on duty in order to let their comrades know that all was well, and to give warning if anything was amiss. ${ }^{4}$

As well as their use as doorbells, classical sources also mention use as animal bells, which is the use highlighted by many modern commentators. ${ }^{5}$ Some early Roman coins bear images of elephants wearing bells around their necks. ${ }^{6}$ More commonly, bells are known to have been used for mule and horse harnesses, as noted in Apuleius' Golden Ass ${ }^{7}$ and as depicted on a relief now in Naples. ${ }^{8}$ In Beuningen (Netherlands) a horse was carefully buried with its headstall; among the studs were a lunula and a domed bell with hexagonal loop. ${ }^{9}$ In such contexts bells may have been amuletic, as has been suggested for early medieval high status male graves containing horses with bells on their harness. ${ }^{10}$ At Kalkriese, the site of the 
Battle of the Teutoburg Forest (A.D. 9) the remains of a mule buried under a bank were found and in-situ around the animal's neck was a large bronze bell. ${ }^{11}$ The bell had been filled with vegetal matter (the stalks of beans or peas) to silence it, and this had been picked fresh from the ground as it still contained roots. ${ }^{12}$ Experiments using a replica suggest that this bell would have been audible for up to $400 \mathrm{~m}$ if rung deliberately, and for up to $200 \mathrm{~m}$ if worn around an animal's neck and sounding as it walked. ${ }^{13}$ That carts may have had bells attached is suggested by the discovery of quadrangular bells next to a cart found in the courtyard of the House of Menander in Pompeii. ${ }^{14}$

Bells were also used to announce the opening - and most likely the closing - of the baths and markets. Martial ${ }^{15}$ tells us that those who do not get to the baths when the bell of the warm bath rings, will end up with a cold bath and Plutarch mentions the market bell. ${ }^{16}$ An official and possibly liturgical function is likely for larger, inscribed bells, such as the example from Tarragona, Spain, thought to have been used as part of the imperial cult, ${ }^{17}$ and bells dedicated to Mercury. ${ }^{18}$

Finally, there are the apotropaic or ritual uses for bells. Juvenal refers to bells used to ward off the eclipse of the moon. ${ }^{19}$ Bells were rung in religious ceremonies and could be attached to the costumes of dancers, for example in Bacchic rituals but also mimes. ${ }^{20}$ As protective charms against the 'evil eye' bells were included in graves. Wind chimes (tintinnabula) and bells were suspended in doorways, houses and gardens to offer protection; splendid examples are known from Vesuvian sites. ${ }^{21}$ Mimicking the use of bells in doorways, Augustus hung bells from the temple to Jupiter Tonans. ${ }^{22}$ Bells of different sizes and types clearly had different functions, and this paper will explore their use in Roman Britain in detail.

\section{METHODOLOGY}

A dataset of 303 bells was collected from published reports, the Portable Antiquities Scheme and some museum collections in 2009. From this, a catalogue was created, which contains detailed descriptions, dimensions, context and site information, references, and scanned images. ${ }^{23}$ The data were entered into an Access database in 2014 by Amy Atkins, and some 
editing and checking of context dates and similar information also took place. Each bell was given a catalogue number, which is provided in the text below and can be used to crossreference information in the database (available on the Archaeological Data Service website: https://doi.org/10.5284/1043774).

Once all the data were collected, the bells were sorted into different typological groups, but establishing a chronology for the bells was difficult due to the nature of the collection, with the PAS and many published finds derived from contexts with limited dating information. Where possible, bell types were cross-referenced to their continental counterparts. Next, the geographical spread was mapped, and any sub-types with regional distributions identified. Finally, the bells' social distribution and contexts were examined. One of the main problems faced during this study was to define context and site types. Many sites had multiple uses over time (such as Colchester) and we also have to face the issue of excavation bias, where there are significantly more military and villa sites excavated than small settlements or vici. ${ }^{24}$ Context information is often limited but where detailed data were available, especially in funerary contexts, temples and hoards it is possible to analyse the ritual and symbolic meaning of bells.

\section{TYPOLOGY AND CHRONOLOGY}

Bells occur throughout the Roman period in a wide variety of shapes and sizes, and it is important for a clearer understanding of the function of the bells to divide them into types. Previously, there has been some terminological confusion, with, for example, examples of 'Type 1 Quadrangular bells' described as 'pyramidal', 'rectangular' and 'sub-rectangular'. ${ }^{25}$ Similarly, for suspension loops the terms pentagonal and hexagonal are frequently mixed up (FIG. 1). This section aims to provide a typological study of both bell and suspension loop types, in order to form an identification system from which finds specialists can work and which can be compared to continental typologies.

Obviously all bells were manufactured with basic features which are dictated by functional requirements. In order to suspend a bell a suspension loop was required and to be heard it needs a clapper. These are rarely found due to loss during use, leading to the bell 
being discarded, and corrosion processes of iron, of which the majority of clappers were made. However, there are several examples where the clappers were made of lengths of copper alloy. ${ }^{26}$ The clapper could be suspended from a loop fastened to the top of the bell or two holes could be drilled and a wire from which the clapper could be suspended was threaded through them. It has been suggested that beads found within bells at Colchester and Scole were replacement clappers, but these are interpreted as votive deposits here (see below); in any case such beads would at best have produced a dull sound. We are aware of one bell with a maker's name (Facundus). ${ }^{27}$

The Romano-British bells were divided into seven typological groups; an eighth group (Openwork bells) is not certainly Roman (FIG. 2).

\section{Type 1: Quadrangular bells}

This form of bell has four sides, with walls that expand out slightly from the top of the bell. Frequently the bell is not square, but rectangular, with the shorter side normally aligned with the loop hole. Many examples have small 'feet' at each corner; these are cast and globular or flat in profile. The suspension loop is usually hexagonal or pentagonal but can be circular (FIG. 2). All the examples of this form originally had an iron clapper hanging from the apex of the bell, but this has either broken off or been lost due to the natural corrosion process, although the corroded residue is frequently visible on the internal apex of the bell, or on the walls.

This type of bell is common in Britain (Total 54), and is found on a variety of military, urban and rural sites. One example is a possible votive offering at one of the springs at Springhead ${ }^{28}$ and another from the Seven Sisters hoard. ${ }^{29}$ Type 1 bells in Britain occur in contexts dated from the second half of the first to the later third century, with the earliest examples found at Fishbourne, ${ }^{30}$ Seven Sisters ${ }^{31}$ and in the foundations of the eastern gateway at Lunt; ${ }^{32}$ there is also a pre-Flavian example from Usk. ${ }^{33}$

\section{Type 2: Domed bells}


Domed bells do not normally have feet, and the suspension loop is usually rounded or hexagonal but can be pentagonal. If the loop is not cast integrally with the bell, wire can be used to suspend the bell (FIG. 2). Some of the examples have incised grooves around the body as decoration; these can be below the loop, in the middle of the body or towards the base. These bells are again commonly found with the remains of iron residue in the apex of the bell, but occasionally, especially in the smallest examples found in burial contexts, they have long, straight copper-alloy clappers, which hang below the base of the bell. This is the most common type (Total 70). The domed group of bells also has a sub-group where the base of the bell has a lip (Total 10; overall Total 80).

Type 2 bells are again attested in a number of pre-Flavian contexts, notably Fishbourne,${ }^{34}$ the Seven Sisters Hoard,${ }^{35}$ Usk $^{36}$ and London Leadenhall Court. ${ }^{37}$ There is also one in a Flavian burial from Winchester. ${ }^{38}$ The many examples from later contexts extend into the third and even fourth century and may indicate that this is a very long-lived type, although some may be residual. Domed bells are known from Anglo-Saxon graves ${ }^{39}$ but these were not counted here. The lipped domed bells are of similar date, with two early examples attested at Hod Hill ${ }^{40}$ and Wanborough. ${ }^{41}$

\section{Type 3: Conical bells}

Whereas the body of Type 2 bells is rounded in form Type 3 bells are conical in shape (Total 46). The suspension loop is usually circular or oval but can be hexagonal, pentagonal or square. As with the domed bells there can be incised circular decoration on the body (FIG. 2). It is noticeable that the majority of Romano-British examples were recorded by the PAS, which may hint at a mainly rural distribution and which also means that there is very little contextual dating evidence. Some may be medieval, but one recently excavated from London, Paternoster Square ${ }^{42}$ is from a context dated to the later second or third century and another is from mid-second-century burial at Pepper Hill, Southfleet $;{ }^{43}$ both context dates chime with continental dates for this type (see below, Table 2).

\section{Type 4: Tulip bells}


Type 4 Tulip bells are in general quite large in size (ranging from $c .35 \mathrm{~mm} \times 74 \mathrm{~mm}$ to 71 $\mathrm{mm} \times 129 \mathrm{~mm}$ ). The apex of the bell is rounded in shape, before narrowing and then flaring out again- very similar in form to an inverted tulip (Total 9; FIG. 2). A Type 4 bell at Binnington Carr was found with twelve silver coins of Caesar, Nero, Vitellius and Vespasian, with the latest coin dated to A.D. $75-6 .{ }^{44}$ Others are found in contexts dated from the second to fourth century, probably residually.

This type of bell may have been used for ritual purposes more often than the smaller types, as one was used to contain a hoard and another comes from the temple at Wanborough. ${ }^{45}$ On the other hand, the tulip bell from Canterbury ${ }^{46}$ was found in the bath palaestra where it may have been used to announce the times for warm baths (see above).

\section{Type 5: Shouldered bells}

Type 5 shouldered bells are on the whole quite small in size and are characterised by a 'step' approximately one-third down from the apex (Total 19; FIG. 2). Bells of this type can have a suspension loop (circular, hexagonal or squared) or the apex can be pierced with two or four holes for suspension. Type 5 is a later form on the continent (see below) and the same appears to be true for Roman Britain, with three examples from contexts dated to the third to fourth century. ${ }^{47}$ A shouldered bell is also known at London, Finsbury Circus, from a burial dated to $c$. A.D. 200-400. ${ }^{48}$ The earliest bell of this type is from Corbridge from a context dated to A.D. 86-163. ${ }^{49}$ A bell from Wroxeter is published as coming from fortress layers, and would thus date to A.D. $60-90$ but it is quite possible that it is in fact from later deposits. ${ }^{50}$

\section{Type 6: Iron bells}

Although the majority of the bells in this study are of copper alloy, there are 8 iron bells from British excavation reports. Iron bells are likely underrepresented within this dataset, as fragmented iron bells may not have been recognised, especially in older excavations prior to the systematic use of X-ray analysis. Metal-detectorists are also much more likely to collect and report copper-alloy rather than iron objects. In most cases these are simple sheets of iron which have been cut, folded and then welded or riveted into shape; iron bells are generally 
much larger than copper-alloy bells, with the exception of tulip bells. Most are roughly rectangular and similar to the Type 1 bells in overall shape, though without that type's characteristic feet (FIG. 2). Two examples appear to have a copper-alloy coating, a feature also noticed on continental examples and thought to be for protection against corrosion rather than to change the sound. ${ }^{51}$

It is often suggested that iron bells are animal bells, with different sizes possibly used for goats and cattle. ${ }^{52}$ It has been suggested that a large iron bell from the Bennecourt (France) sanctuary may have been worn by a sacrificial beast. ${ }^{53}$

Examples from dated contexts are known at Caerleon, ${ }^{54}$ Vindolanda, ${ }^{55}$ Maiden Castle ${ }^{56}$ and Frocester. ${ }^{57}$ This may point to a late Roman date overall.

\section{Type 7: Miscellaneous bells}

This section includes bells which do not fit into any of the other categories, often because they are fragmentary or poorly illustrated (Total 53). The unusual bells include very large examples from Wanborough (diameter $80 \mathrm{~mm}$ ) and Castle Collen (diameter $98 \mathrm{~mm}) .{ }^{58} \mathrm{~A}$ bell from an early third-century child's burial at Brougham proved difficult to classify as it is domed and lipped but also has a slight step at the apex. ${ }^{59}$

Two highly unusual bells come from the Romano-British temple on Cold Kitchen Hill in Wiltshire (FIG. 2). One has a lion's head in relief, a motif common on furniture studs, ${ }^{60}$ while the other is described as depicting human figures. ${ }^{61}$ Relief-decorated bells are very rare; there are a few examples decorated with images of the god Bes and animal heads from Roman Egypt ${ }^{62}$ and the British Museum also houses a pair of miniature gold bells decorated with the labours of Hercules said to be from Tarsus, Turkey. ${ }^{63}$

\section{Openwork bells}

Not included in the original dissertation, this is a new form of bell that has recently been recognised on the PAS, with 26 examples recorded by 2016 (see Table 1). The bells are all made from copper-alloy, domed or conical in form and have distinctive triangular cut-outs, which can be arranged in a variety of patterns (FIG. 3). The most common design consists of a 
band of triangles set in an alternating pattern (apex to base). The number of triangles varies (and can often not be determined as many bells are only partially preserved), with the most common number being six and the maximum $12 .{ }^{64}$ In one case there are only four very crude triangles that all appear to be aligned the same way (base down). ${ }^{65}$ Some bells are decorated with more complex patterns; thus two similar but very fragmentary examples from Norfolk and Essex appear to have two rows of triangles aligned the same way (base down). ${ }^{66}$ Two additional triangles (apex down) are set above an alternating band in a bell from Suffolk ${ }^{67}$ while other bells have pairs of opposing triangles separated by single triangles or other shapes. Thus SF-A755C5 from Great Barton (FIG. 3) has four pairs of opposing triangles set one above the other base to base, separated by single apex-up triangles while ESS-954081 has six pairs, either opposing triangles (apex to apex) or a triangle above a rectangle. Two very similar examples from Norfolk and Cambridgeshire have a flower design created by four inward-pointing triangles; set between them is a pair of triangles, again with the apex pointing towards each other. ${ }^{68}$ Perhaps the most elaborate example has a design of two rows of alternating triangles. ${ }^{69}$ While there is variation in the number and alignment of the triangles, this is clearly a distinctive form of bell, usually with pentagonal or hexagonal loops. Even where the loop shape is unusual and where production at the same workshop may be assumed, the number of triangles can vary. ${ }^{70}$ Three bells cross-referenced on the PAS from Monks Eleigh, Covehithe and Beeston with Bittering either have no perforations ${ }^{71}$ or circular perforations. ${ }^{72}$ The clapper only survives very rarely ${ }^{73}$ but several examples have significant interior iron corrosion, in some cases completely filling the triangles.

The purpose of the triangles is unclear - openwork decoration works best visually when set against leather or fabric for contrast or when filled with enamel; the latter does not appear to be the case here and the former would render the object non-functional. Perhaps the aim was simply a decorative effect or the intention may have been to alter the sound produced by the bells. Unfortunately no openwork bells are as yet known from excavated contexts in Britain, and there is consequently no contextual dating evidence. It is possible that they are a much later type, or even a modern import, although the wide spread is unlike the pattern created by metal-detector rallies where a site may have been 'seeded' with material 
bought on eBay. The distorting effect of modern imports is well demonstrated by coins with eastern Mediterranean mint marks from Scotland, which are in fact modern losses. ${ }^{74}$

Bells of this type were originally thought to be of medieval date but research on 'Norse' bells has shown all certain examples to be of hexagonal shape, often with circle-anddot decoration; the openwork bells are circular in plan and domed or conical, and the loop shapes are very similar to Roman bells. The openwork bells are broadly similar to domed bells in terms of their dimensions, ranging in height from $12 \mathrm{~mm}$ to $35 \mathrm{~mm}$. Openwork bells also have a very different spatial distribution to the tenth-century bells with Scandinavian affiliations, ${ }^{75}$ with the majority occurring in the south of Britain (see FIG. 6).

Until examples from excavated contexts are found in Britain, the date and origin of this enigmatic bell type will remain unclear. The only continental parallels we were able to identify come from the Black Sea region (see below). ${ }^{76}$

\section{Non-Roman rumbler bells}

Eight bells that appear to have a closed form, often made in two halves, and originally containing a pellet were found during the literature search (FIG. 2). Unstratified examples come from Roman sites such as Verulamium and South Shields, and from two villa sites where the bells are said to be associated with first- and second-century material. ${ }^{77}$ Such rumbler bells are usually thought to date from the thirteenth century onwards although some earlier medieval examples are known from the continent. ${ }^{78}$ This is not a Roman type, and it is most likely that these bells are in fact of much later date and intrusive in roman layers.

\section{BELLS IN OTHER PARTS OF THE ROMAN EMPIRE}

Bells are frequent finds across the Roman Empire, but it is not the purpose of this paper to offer a full review of the continental material. However, we may note some large assemblages such as Augst, Vitudurum, Kempten and Lyon. ${ }^{79}$ A very interesting phenomenon is the export of Roman bells into the Barbaricum, where they have mainly survived in burials. ${ }^{80}$ 
Most continental typologies are based on that of Nowakowski ${ }^{81}$ and have been summarised by Flügel. ${ }^{82}$ This can be compared to a recent analysis by Nicolay ${ }^{83}$ and an attempt by Furger and Schneider ${ }^{84}$ to modify these typologies to more carefully reflect production techniques.

The continental data compare well with the British material both in terms of typology and chronology, although the continental material obviously has an earlier start date.

\section{SOCIAL AND SPATIAL DISTRIBUTION}

To assess the bells' social distribution, the sites from which they were recorded were classified according to the methodology set out by Eckardt (FIG. 4). ${ }^{85}$ Major towns include London, Verulamium and the civitas capitals; small towns are those defined by Burnham and Wacher ${ }^{86}$ and military sites encompass legionary fortresses, auxiliary forts and marching camps and their associated vici. In cases where there is both a military and an urban site (e.g. York or Colchester) and finds are without exact findspots or stratigraphic information, the value is split. The finds from the Romano-British countryside are divided into those from villas, those from other small settlements or shrines and the many bells recorded by the PAS, which do not have archaeological contexts but are likely to be from rural settlements.

The social distribution is heavily skewed towards the PAS data, which hugely increases the number of bells that probably came from rural sites; among the excavated sites military and urban settlements dominate. The context categories can then be broken down further to identify bells that were found in burials, hoards or temple areas (see below).

In terms of the spatial distribution, it is clear from the just over 300 bells recorded that these objects were in common use throughout Britannia (FIG. 5). They are found as far north as Scotland ${ }^{87}$ and as far south as the Isle of Wight, with multiple finds mainly from major sites such as Colchester and London. A group of fourteen quadrangular bells were found at Coggeshall, half way between Colchester and Braintree, Essex. Denison ${ }^{88}$ has claimed that the fact that they were discovered 'in a ring' meant that they were buried deliberately, 'perhaps as part of some forgotten ceremony'. Others suggest that they were accidently lost on their way to market; all 14 are of the same type but slightly different dimensions and they 
may have been tied together for safe transport. ${ }^{89}$ Areas with few or no bells such as the Weald, the south west and north-west may reflect ancient practice but also of course patterns in settlement, metal-detecting and excavation; the concentration in East Anglia is typical of PAS data, for example, and reflects the fact that 153 of the 303 bells recorded here come from metal-detected finds. ${ }^{90}$

For the purpose of this paper we have only mapped Openwork bells in detail as this is an unusual and new form of possibly Roman date. It is evident that this type has an essentially southern (and south-eastern) distribution (FIG. 6). The most northerly example recorded by the PAS are Yorkshire (Grimsby and Skirpenbeck). The overall distribution varies from that of Norse bells, ${ }^{91}$ and would appear to be more typical of either Anglo-Saxon or Roman objects, with the multiple finds in the east characteristic of many PAS maps and essentially reflecting metal-detecting patterns. ${ }^{92}$ A number come from near Roman roads (e.g. Skirpenbeck, Stoke Hammond, a group in Norfolk around the terminal of Peddars Way) and this may hint at the means by which these particular objects were moved across the province.

We have been unable to find published parallels for this bell type in Britain and across the Roman Empire. However, there are strikingly close examples from a very distant region, namely the area around the Black Sea (see Table 3, FIG. 7).

These bells all have various arrangements of alternating and opposing triangles in the same style as the British examples, and similar loop shapes. Where this information is available they are perhaps slightly larger than the British examples (e.g. heights of 3.9 and $4.8 \mathrm{~cm}$ ) but overall they are clearly very similar to the British PAS bells. Only one (Valea Lupului, Romania) is of a late Roman date while the remainder are thought to date to the (?later) first century. ${ }^{93}$

Recently, Daniel Kostromichev has kindly drawn our attention to further examples from the region (FIG. 8). They are also generally dated to the first and second century and broadly associated with Sarmatian groups, and many come from burials, including those of children. ${ }^{94}$ There are conflicting views as to the place of manufacture of these perforated bells. Nowakowski ${ }^{95}$ sees them as 'East-Sarmatian' products, or perhaps more broadly as local to the Black Sea region; however, Simonenko et al. ${ }^{96}$ note that the form is rare 
compared to plain bells in the same region and suggest that they may be imported although they do not specify where their source may lie. Standard Roman bells are quite commonly found in cemeteries within this region, where they can occur on items of female costume such as belts. ${ }^{97}$ Thus by no means all bells in this region are of the openwork type.

If we assume that the British finds are genuine and of Roman date, it is difficult to explain their relationship with the Russian and Ukrainian parallels. The Black Sea region was wealthy in Antiquity, and from the first century B.C. Roman onward control increases through the establishment of provinces (Pontus and Bithynia, Moesia), the transformation of the Bosporan kingdom into a client kingdom and the presence of Roman garrisons in the Crimea; in general, the whole region was closely connected to the Mediterranean and the wider Roman Empire. ${ }^{98}$ However, trade and general contact ought to result in finds across the Mediterranean or along the Danube. This is the case for cast buckles that were part of Roman military costume and widely copied in the Black Sea region; they are usually dated to the second quarter of the second century to the early fourth century and occur not just in the Crimea but along the Danube and Rhine as well as in Britain. ${ }^{99}$

The occurrence of bells of this form apparently only in two regions without finds from the intermediate areas might appear to be more typical of the movement of people, most likely connected to the military. Movement of objects or people from the Black Sea to Britain may be thought to relate to the presence of Sarmatians in Britannia, a phenomenon that has been much debated. While there is epigraphic and sculptural evidence, the suggestion that objects such as gold-in-glass beads indicate a Sarmatian presence is much more contentious; in any case any Sarmatian presence is usually thought to date to the reign of Marcus Aurelius and later. ${ }^{100}$ The Roman military presence on the Black Sea coast and the Crimea is now quite well documented ${ }^{101}$ and the date of the bells may relate to a peak of Roman military activity during the Neronian period ${ }^{102}$ but to our knowledge only one of the units attested in the region has possible links with Britain. However, while Legio VIII is attested in Moesia most commentators are now not certain that this unit was involved in the conquest of Britain as had been previously thought. ${ }^{103}$ 
No firm conclusion can be drawn at this point, but it is hoped that bells with triangular openwork are found in stratified contexts in the future so that their origin and date may be resolved.

\section{THE RITUAL AND APOTROPAIC FUNTION OF BELLS}

One of the most intriguing aspects of the bells was their use as part of apotropaic or 'good luck' charms, and the part they played in both burial and religious rituals. This section will not only examine the bells from Britannia, but also examples for which ritual use can be suggested both in the Empire and the Barbaricum. Bells are thought of as magical in other cultures and times, for example in pre-Columbian Mesoamerica where bells 'offered protection in war and structured rituals that celebrated fertility and regeneration' and the sounds and colour of the metal 'constituted a system of visual and aural symbols that created and recreated the experience of the sacred' ${ }^{104}$ A handbell or set of small handbells is rung at significant moments during the Catholic mass.

Tintinnabula were wind-chimes to be hung out in the garden or courtyard, which make a pleasant tinkling noise as they blow in the breeze. However, they also functioned as apotropaic charms against the 'evil-eye'. Approximately thirty examples are known, and most form part of a group of ithyphallic objects in order to give the owner a perceived sense of extra good luck. ${ }^{105}$ Other examples of bells used in domestic ritual are also known. Seven bells were suspended from a bust of Mercury from Orange, France (FIG. 9). ${ }^{106}$ Some hoard finds containing copper-alloy figurines that are presumably derived from shrines include bells, such as those from Brèves and La Comelle-sous-Beuvray. ${ }^{107}$

That bells were associated with luck is also demonstrated by the dice tower from Froitzheim (Germany), where originally three bells hung just above the stairs down which the dice would have tumbled. ${ }^{108}$ Another curious example comes from a grave in Rebenstorf (Free Germany), where a bronze container has three small bells fitted to its outside, possibly to protect its contents. ${ }^{109}$

Bells with beads inside them may have functioned as votive offerings. In Colchester Culver Street a Type 1 bell was found in the floor make-up/dump of Building $120 .{ }^{110}$ Inside 
the bell was a blue frit melon bead. More recently, at the Roman small town of Scole in Suffolk, a Type 4 tulip bell was discovered underneath a packed flint threshold to a small building. ${ }^{111}$ Once it was conserved, three blue frit melon beads were discovered inside the bell. Beads, and especially melon beads, were thought to have magical properties and may have been associated with bells as amulets, as in a small hoard from Augst (Switzerland), which contained melon beads, bronze rings and bells. ${ }^{112}$ Two melon beads were found strung along with a bell, pierced coins and boar tusk amulets in a child's grave at Rouen, France. ${ }^{113}$ In the Winchester Grange Road grave discussed below both a bell and eight melon beads were among the finds. ${ }^{114}$ At the Bloomberg (London) site a melon bead was found in association with a bone hand and phallus amulet. ${ }^{115}$ Overall, the deposition of beads and bells in doorways might therefore point to them acting as protective or votive offerings. ${ }^{116}$

\section{BELLS IN THE FUNERARY RECORD}

One context in which bells may have served an apotropaic function is as amulets, and this is occasionally evident in the funerary record. ${ }^{117}$ For example, in several of the catacombs of Rome, bells were found to have been placed in the soft mortar surrounding the loculi (niches) of children. ${ }^{118}$ In Pompeii's Porta Nocera cemetery a child aged between three and ten months was buried with a phallic amulet and a bracelet with an attached bell; this is thought by the excavators to be a girl. ${ }^{119}$ Martin-Kilcher, in her discussion of mors immatura, discusses the number and variety of amulets that have been found in the burials of young women, and classifies them as crepundia, or objects that rattle or make a noise. ${ }^{120}$ These were either worn on a string, chain or on rings and it is thought that their noise was important for their 'effect and function', in this case the protection from the dead. ${ }^{121}$ There are many examples of bells in continental graves, including those of children. ${ }^{122}$ Bells occur in children's graves in Gaul, often associated with other amulets or protective charms. ${ }^{123}$ From Arras there is an example of a child's grave where a bell is combined with a phallic amulet, much as in the Colchester grave discussed below. ${ }^{124}$ Bells were used in the Byzantine period to ward off evil spirits, especially from children; John Chrisostom condemns women for tying bells to the hands of children in the late fourth century but there are Byzantine graves with 
bells demonstrating that this practice existed. ${ }^{125}$ Bells also occur in Anglo-Saxon graves, where they are usually interpreted as belonging to animals, ${ }^{126}$ but this should perhaps be rethought.

In the Romano-British dataset 17 bells were found in 16 graves; there is also one (No. 102) that could not be attributed to a specific grave in the densely packed Trentholme Drive cemetery at York. ${ }^{127}$ Where sexing and/or ageing was possible, these are the graves of either women or young children (Table 4).

Female graves were identified both on the basis on osteological information and grave goods. At the St Bartholomew's Hospital site in London a bell was found in the fill above the coffin of a young female, aged 17-24, who had been buried with seven bracelets and two finger rings placed onto her chest. ${ }^{128}$ The late Flavian Grave 2 at Winchester Grange Road contained feasting (a shale tray, multiple ceramic vessels, copper-alloy and glass jugs) and writing (a seal-box, ${ }^{129}$ two styli, a pen knife, an iron double-ended spatula) equipment as well as 18 glass counters, a spoon, melon beads and a piece of banded flint. The grave was mistakenly thought by Biddle to be male on the basis of the grave goods but the osteological analysis suggested that 'the cremated remains are those of an immature individual, perhaps a teenager or a fairly slender female'. ${ }^{130}$ Multiple beads and in one case a hairpin from two graves at Winchester Victoria Road suggest that they are of females; one is an adult but the bone for the other is lost. ${ }^{131}$ In a first-century A.D. cremation at Winchester Hyde Street a mature woman was buried with a child of $c .3$ years, and it is not possible to determine with which individual the bell was associated. ${ }^{132}$ In the Pepper Hill cemetery at Southfleet a woman was buried with an infant; the only grave goods accompanying the second-century urned cremation were the bell and a torc-twisted bracelet or necklace. ${ }^{133}$ At the Finsbury Circus site in London the inhumation grave (dated to $c$. A.D. 200-400) of an unsexed adult aged 36-45 years buried with an infant, possibly a neonate, cradled on the chest is probably that of a woman. Two ceramic beakers were placed by the right shoulder and by the skull of the adult; the bell was found on the right side of the adult's pelvis, by the feet of the infant. ${ }^{134}$ All remaining graves are those of children, with three known from the later Roman Colchester Butt Road cemetery. The bell from G1 was found in the grave of a girl around ten 
years of age, and was attached to a copper alloy armlet on which there was also a bead. ${ }^{135}$ The second grave, G94, is the inhumation of a child and contained two bells on a short length of chain. ${ }^{136}$ Both date to Period 2, the mid- to later fourth century. The final grave, G278, contained what appears to be a chain purse containing several amuletic objects. Among the objects were the bell, an amber pendant in the form of a human head with a possibly phallic nose, a small copper alloy horned phallus and two pierced coins (FIG. 10). This grave is dated to Period 1 (pre-A.D. 320/40); there was no evidence of any remains in the grave, but the size of the grave cut indicated that it, too, belonged to a child. ${ }^{137}$ At a grave in Guilden Morden the bell was hung on the wrist of a child of unspecified age, together with two beads. ${ }^{138}$

One burial from Chichester (Burial Group 11) contained a child burial with grave goods consisting of an iron bell, a red-slipped carinated bowl with a graffito of a cross on the base, and a small pebble. ${ }^{139}$ The authors claim that both the bell and the pebble represent toys, but they could also be classed as crepundia. At the military cemetery at Brougham, which is argued to be the final resting place of people with Danubian origins, a bell was placed (apparently unburnt) into the BB1 jar that also contained the cremated remains of a 34 year old child; there were three further ceramic vessels, one of which covered the jar. ${ }^{140} \mathrm{~A}$ bell and a single nail were found in a neonate's ( $0-4$ weeks) burial at Springhead, Kent, and both may have had an apotropaic meaning for the parents. ${ }^{141}$ It is possible that the vessel into which the newborn had been placed contained the remains of another neonate; it was placed in one of the sanctuary areas of the site (Property 2, which includes a temple).

While a small dataset, the evidence from Britain certainly seems to suggest that bells were used as amulets, sometimes associated with other apotropaic objects such as a pierced dog's canine or melon beads; they were especially associated with children and women.

\section{THE RITUAL USE OF BELLS IN TEMPLES}

Tintinnabula may have been linked to Priapus and at Aventicum (Avenches, France) a large Type 2 bell with a dedication to Mercury was discovered just to the west of the sanctuary area of the town. ${ }^{142}$ Although only a small fragment of the bell survives, the key fragment with the inscription to Deo Mer still survives. Although inscribed bells are rare, several have 
been found on the continent with inscriptions to Mercury, perhaps invoking his role as mediator between men and gods. ${ }^{143}$ Generally, an association of bells with sanctuaries has been suggested, as with the bell from the temple at Sichelen and votive deposit of eight small bells from the sanctuary at Les Bolards, Nuits-Saint-Georges, France. ${ }^{144}$

Bells have also been found on a number of Romano-British temple sites. Two bells from the poorly understood religious complex at Cold Kitchen Hill in Wiltshire have figurative decoration that may be of ritual significance. One is decorated with a lion's head, the other has two human figures. ${ }^{145}$ At the Green Lane site in Wanborough, Wiltshire, a Type 4 Tulip bell was discovered in the area around the religious site and the author believes that it may have either hung around the neck of an animal, or may have been used during rituals. ${ }^{146}$ Bells have also been found on temple sites at Maiden Castle, ${ }^{147}$ Corbridge, ${ }^{148}$ Haddenham ${ }^{149}$ and Woodeaton. ${ }^{150}$ In all these instances there is no certain association with the temple and the activities that took place within it, but for the Mithras cult a case for the ritual use of bells can be made. This secretive cult, mainly associated with the military and only open to men, held their meetings in cavern-like locations, so recreating the myth of Mithras, who slayed a bull in a cave. ${ }^{151}$ At Segontium (Caernarvon) several iron fragments were found at the base of an altar within the third-century mithraeum, which are thought to be from a tall candleholder or standard; a small copper alloy bell may have been hung from its two arms. ${ }^{152}$ Another bell of Type $2 \mathrm{a}$ form was found in the Mithraeum at Tienen in Belgium ${ }^{153}$ and two iron bells are known from the mithraeum at Strassbourg. ${ }^{154}$ It has been suggested that bells were rung to increase the audience's attentiveness at certain points in the narration of the myth. ${ }^{155}$

In some cases bells were among votive offerings, most notably in the case of Coventina's Well on Hadrian's Wall. ${ }^{156}$ In a less formal context, it is also possible that the bell found with Roman pottery, an iron knife, oyster shells, burnt sticks as well as human and animal bones in a deep shaft at Plumstead were ritual offerings. ${ }^{157}$

\section{BELLS IN HOARDS}

Several bells have been discovered in hoards in Britain. At Binnington Carr in North Yorkshire, a Type 4 Tulip bell was discovered in a ploughed field in $1876 .{ }^{158}$ Placed inside 
the bell were twelve silver coins, including one of Julius Caesar (49-44 B.C.), Nero (A.D. 5468), three of Vitellius (A.D. 69), and seven of Vespasian (A.D. 69-79). At the Saxon Shore Fort of Burgh Castle, Norfolk, a Type 1 Quadrangular bell was discovered in a pit with a hoard of glass vessels and a small bronze vessel. The hoard was placed in a bronze bowl, and all the items were contained within an iron-bound bucket. ${ }^{159}$ Two bells were part of the Seven Sisters (near Neath, Wales) hoard discovered in 1875 and dated to A.D. 50-75 on the basis of Roman military equipment; the 37 objects recovered consist of horse gear, tankard handles as well as ingots, scrap metal and two casting jets, with the latter leading to the suggestion that this could be a metalworker's hoard. ${ }^{160}$ The hoard comprises objects of both 'Roman' and 'native' style and manufacture; more recent metal analysis showed differential use of alloys and the uptake of Roman techniques such as brass and enamels in the post-conquest period. ${ }^{161}$

Bells also occur in hoards on the continent, both within the Empire and in the Barbaricum; examples include the hoard associated with a shrine to Dolichenus at Mauer-ander-Url in Austria ${ }^{162}$ and the so-called Alemannic booty from the Rhine at Neupotz, Germany. ${ }^{163}$ At Havor, in Gotland, a hoard was buried within a ring fort, which on the evidence of the finds was of first-century date. ${ }^{164}$ The hoard consisted of a bronze situla, a large gold torc, a wine ladle and strainer and two large Type 4 Tulip bells, which had been tied to a ring using a leather strap. Beside the bells were a stack of small copper alloy saucepans, placed one inside the other. ${ }^{165}$

River finds may be seen as votive but unfortunately the only information for the example from the Thames (No. 4) is that it came from the northern foreshore. ${ }^{166}$

\section{CONCLUSION}

This study analysed a corpus of just over 300 published and unpublished bells from Roman Britain, with a database of this material now available on the ADS website (https://doi.org/10.5284/1043774). It has identified clear types, and explored their possible functions. While iron bells may well have been used for animals and large forms such as tulip bells may have functioned as door, market or warning bells, many of the smaller forms 
appear to have had broadly amuletic or apotropaic functions. The use of a bell clearly depended on its size and material, and some objects appear to show long use, possibly in a variety of functions. We have summarised the available dating evidence from the province and the Continent, demonstrating that bells were used throughout the Roman period but with a peak in the first century.

Many of the types can be paralleled on the continent but this paper also identified a new bell type, which is characterised by triangular cut-outs in a variety of arrangements. Unfortunately all examples from Britain were recorded by the PAS, with none known from excavations. This is an unusual pattern, given that quite significant numbers have now been recorded but there is no particular reason for seeing the PAS finds as modern imports. The finds come from widely dispersed sites (i.e. not from a small number of rallies by the same metal-detecting club) and while some are well preserved there are also many fragmentary examples, Doubts remain whether this openwork type really is Roman but it differs in details of design and distribution from early medieval bells. The only parallels we were able to identify are of first-century date and come from graves in the Black Sea region, a pattern that is difficult to explain. It is hoped that future finds will come from excavated contexts, so that the type can be more securely dated and its origin established.

An analysis of social distribution suggests that bells were used across the settlement hierarchy; among the excavated material there is an emphasis on military and urban sites but this is balanced by the new data available from the PAS, which shows the widespread use of all types on rural sites. Bells occur on temple sites and in hoards but contextual information for temples is quite poor, and they may occur in hoards for their metal value, as containers or for the sound they produced. We have much better information on the use of bells as amulets, in particular from the graves of children and young women. In these cases, it must have been the sound of the bells that exerted magical and protective powers. As suggested by Schoenfelder and Richards bells represent an 'audible form of ostentation' 167 and, we would argue, magic.

\section{APPENDIX}


Table 1.

Table 2.

Table 3.

Table 4.

\section{ACKNOWLEDGEMENTS}

The authors thank Amy Atkins, who transcribed the original catalogue onto an Access database. The paper was written during study leave supported by the Department of Archaeology, University of Reading. We would like to thank John Creighton, Nina Crummy, Michel Feugère, Stefanie Hoss, Daniel Kostromichyov, Michael Marshall and Julian Richards for additional information. Matt Fittock, Owen Humphreys and Philippa Walton kindly commented on an earlier draft of this paper. Illustrations were produced by Jennifer Foster and Sarah Lambert-Gates, and we thank Devizes Museum for the photo of a bell from Cold Kitchen Hill, Sally Worrell for the images from the Portable Antiquities Scheme and the Bibliothèque nationale de France for permission to reproduce the Mercury bust from Orange. Rob Fry kindly produced the GIS density map.

Department of Archaeology, University of Reading

h.eckardt@ reading.ac.uk

84 Hithercroft Road, High Wycombe, Bucks, HP13 5RH

sandie.williams2williams@btinternet.com

\section{ANCIENT SOURCES}

Aeschylus: Seven against Thebes, trans. G Hutchinson, Oxford (1985)

Apuleius: The Golden Ass, trans. P.G. Walsh, Oxford (1994)

Dio Cassius: Roman History, trans. E. Cary, Loeb Classical Library, Cambridge. Mass./London (2000) Juvenal: Satires, trans. N. Rudd, Oxford (1991) 
Martial: Epigrams, trans. R. Shackleton Bailey, Loeb Classical Library, Cambridge.

Mass./London (1993)

Plutarch, Life of Aratus: Lives, trans. B. Perrin, London (1926)

Plutarch: Symposiacs, https://ebooks.adelaide.edu.au/p/plutarch/symposiacs/

Plautus: Pseudolus, trans. E.F. Watling, London (1965)

Suetonius, Life of Augustus: The Twelve Caesars, trans. Michael Grant, London (1989)

\section{BIBLIOGRAPHY}

Allason-Jones, L., and McKay, B. 1985: Coventina's Well: A Shrine on Hadrian's Wall, Hexham

Anderson, A.S., Wacher, J.S., and Fitzpatrick, A.P. 2001: The Romano-British Small Town at Wanborough, Wiltshire, London

Anderson, R.D. 1976: Catalogue of the Egyptian Antiquities in the British Museums III: Musical Instruments, London

Andringa, W. van, and Lepetz, S. (eds) 2013: Mourir à Pompéi: fouille d'un quartier funéraire de la nécropole romaine de Porta Nocera (2003-2007), Rome

Ashwin, T., and Tester, A. 2014: A Roman Settlement in the Waveney Valley: Excavations at Scole 1993-4, Dereham

Bagnall-Smith, J. 1999: 'More votive finds from Woodeaton', Oxoniensia 63, 147-85

Bakushev, M.A, and Ilyukov, L.S. 2012: Bronze hand bells of the Albano-Sarmatian time from the territory of Dagestan, ВЕСТНИК ЮЖНОГО НАУЧНОГО ЦЕНТРА РАН 8.3, $78-83$

Bentley, D., and Pritchard, F. 1982: 'The Roman cemetery at St Bartholomew's Hospital', Transactions of the London and Middlesex Archaeological Society 33, 134-72

Bekker-Nielsen, T. (ed.) 2006: Rome and the Black Sea Region: Domination, Romanisation, Resistance, Aarhus and Oakville

Biddle, M. 1967: ‘Two Flavian burials from Winchester', Antiquaries Journal 47, 224-50

Biddulph, E., Seager Smith, R., and Schuster, J. 2011: Settling the Ebbsfleet Valley. Vol. 2: Late Iron Age to Roman Finds Reports, Oxford 
Bidwell, P.T. 1985: The Roman Fort at Vindolanda at Chesterholm, Northumberland, London

Birbeck, V., and Moore, C. 2004: 'Preservation and investigation of Roman and Medieval remains at Hyde Street, Winchester', Proceedings of the Hampshire Field Club and Archaeology Society 59, 77-111

Bishop, M.C., and Dore, J.N. 1988: Corbridge: Excavations of the Roman Fort and Town, 1947-1980, London

Bishop, M.C. 1996: Finds from Roman Aldborough: A Catalogue of Small Finds from the Romano-British Town of Isurium Brigantum, Oxford

Blockley, K., Blockley, M., Blockley, P., Frere, S.S., and Stow, S. 1995: Excavations in the Marlowe Car Park and Surrounding Areas, Canterbury

Blunt, R. 2005: Crotal bells. http://www.ukdfd.co.uk/pages/crotal-bells.html (accessed 20/10/2016)

Boon, G. 1960: ‘A Temple of Mithras at Caernarvon-Segontium’, Archaeologia Cambrensis $109,136-72$

Boon, G. 1978: 'More finds from Castle Collen Roman fort', Radnorshire Society Transactions 48, 17-19

Booth, P., and Cool, H.E.M. 2006: The Small Finds from Pepper Hill, Southfleet, Kent, CTRL Specialist Archive Report http://archaeologydataservice.ac.uk/archiveDS/archiveDownload?t=arch-3351/dissemination/pdf/PT2_Spec_Reps/03_Small_finds/SFS_research_reports_SmallFinds Text/SFS_PHL_text.pdf

Borrill, H. 1981: 'Casket burials', in C. Partridge, Skeleton Green: A Late Iron Age and Romano-British site, London, 304-21

Boucher, S., Perdu, G., and Feugère, M. 1980: Bronzes antiques du Musée de la Civilisation Gallo-Romaine à Lyon II (Instrumentum, Aegyptiaca), Paris

Bourgeois, L. (ed.) 1999: Le sanctuaire rural de Bennecourt (Yvelines), Paris Brailsford, J.W. 1962: Hod Hill, Volume 1: Antiquities from Hod Hill in the Durden Collection, London 
Brindle, T. 2014: The Portable Antiquities Scheme and Roman Britain, London

Burnham, B.C., and Wacher, J.S. 1990: The 'Small Towns' of Roman Britain, London

Caballero Zoreda, L. 1990: Los bronces romanos en España, Madrid

Casey, J. 1986: Understanding Ancinet Coins, London

Clarke, D.V. 1972: 'Four Roman bells from Scotland', Proceedings of the Society of Antiquaries of Scotland 103, 228-31

Clauss, M. 2001: The Roman Cult of Mithras, Cambridge

Cocks, A.H. 1921: ‘A Romano-British homestead in the Hambleden Valey, Bucks.', Archaeologia 21, 141-98

Cojocaru, V., Coşkun, A., and Dana, M. (eds) 2014: Interconnectivity in the Mediterranean and Pontic World during the Hellenistic and Roman Periods, Cluj-Napoca

Cool, H.E.M. 2004: The Roman Cemetery at Brougham, Cumbria. Excavations 1966-67, London

Cool, H.E.M., Lloyd-Morgan, G., and Hooley, A.D. 1995: Finds from the Fortress: The Archaeology of York, the Small Finds 17/10, London

Cowan, C. 1992: 'A possible mansio in Roman Southwark: excavations at 15-23 Southwark Street 1980-86', Transactions of the London and Middlesex Archaeological Society 43, 3193

Crawford, M.H. 2001: Roman Republican Coinage Vol. 2, Cambridge

Crummy, N. 1983: The Roman Small Finds from Excavations in Colchester 1971-9, Colchester

Crummy, N. 2010: 'The iconography of protection in late Roman infant burials', Britannia 41, 37-93

Crummy, N., Crossan, C., and Crummy, P. 1993: Excavations of Roman and Later Cemeteries, Churches and Monastic Sites in Colchester, 1971-88, Colchester

Crummy, P. 1992: Excavations at Culver Street, The Gilberd School and Other Sites in Colchester, 1971-85, Colchester

Cunliffe, B. 1971: Excavations at Fishbourne 1961-1969. Volume 2: The Finds, London 
Dasen, V. 2003: 'Les amulettes d'enfants dans le monde gréco-romain', Latomus 62.2, 27589

Dasen, V. 2005: 'Protéger l'enfant: amulettes et crepundia', in D. Gourevitch, A. Moirin and N. Rouquet (eds), Maternité et petite enfance dans l'antiquité romaine, Bourges, 179-84

Dasen, V. 2015: 'Probaskania: amulets and magic in antiquity', in D. Boschung and J.

Bremmer (eds), The Materiality of Magic, Paderborn, 177-203

Davies, J.L., and Spratling, M.G. 1976: 'The Seven Sisters hoard: a centenary study', in G.C. Boon and J.M. Lewis (eds), Welsh Antiquity: Essays Mainly on Prehistoric Topics Presented to H.N. Savory upon his Retirement as Keeper of Archaeology, Cardiff, 121-47

Davis, M., and Gwilt, A. 2008: 'Material, style and identity in first century AD metalwork, with particular reference to the Seven Sisters hoard', in D. Garrow, C. Gosden and J.D. Hill (eds), Rethinking Celtic art, Oxford, 146-84

Denison, S. 2000: 'From a stolen seal to a buried Brahma', British Archaeology 55 http://www.archaeologyuk.org/ba/ba55/ba55news.html (accessed 20/10/2016)

Deschler-Erb, E. 1996: 'Die Kleinfunde aus Edelmetall, Bronze und Blei’, in Beiträge zum römischen Oberwinterthur - Vitudurum 7. Ausgrabungen im Unteren Bühl, Egg/Zürich, $13-139$

Dierichs, A. 1999: 'Klingendes Kleinod. Ein unbekanntes Tintinnabulum in Dänemark', Antike Welt 30, 145-9

Dierichs, A. 2009. 'Tintinnabulum', in H. Cancik and H. Schneider (eds), Brill's New Pauly: Encyclopaedia of the Ancient World, Leiden, 720-1

Down, A., and Rule, M. 1971: Chichester Excavations I, Chichester

Drescher, H. 1998: 'Rekonstruktionen und Versuche zu frühen Zimbeln und kleinen antiken Glocken', Saalburg Jahrbuch 49, 155-70

Eckardt, H. 2005: 'The social distribution of Roman artefacts: the case of nail-cleaners and brooches in Britain', Journal of Roman Archaeology 18, 139-60

Eckardt, H. 2014: Objects and Identities: Roman Britain and the North-western Provinces, Oxford 
Egan, G., and Pritchard, F. 1991: Dress Accessories c. 1150-1450. Medieval Finds from Excavations in London, London

Erdrich, M. 2002: Corpus der römischen Funde im Barbaricum 4 (Hansestadt Bremen und Bundesland Niedersachsen), Bonn

Espérandieu, E. 1911: 'Tintinnabula', in C. Daremberg and E. Saglio (eds), Dictionnaire des antiquités grecques et romaines, Paris, 341-4

Evans, C., and Hodder, I. 2006: Marshland Communities and Cultural Landscape: The Haddenham Project II, Cambridge

Evans, D.R., and Metcalf, V.M. 1992: Roman Gates Caerleon, Oxford

Flügel, Ch. 1993: Die römischen Bronzegefässe von Kempten-Cambodunum. Materialhefte zur Bayerischen Vorgschichte A63, Kallmünz, 53-114

Forrer, R. 1919: 'Römische Mühlen-, Töpferei- und Handelsbetriebe, Metallwerkstätten und Waffenfunde in Strassburg', Cahiers Alsaciens d'Archéologie, d'Art et d'Histoire 10, 988-1078

Frere, S.S. 1984: Verulamium Excavations Volume III, Oxford

Froehner, W. 1872: Les musées de France, Paris

Furger, A.R., and Schneider, C. 1993: 'Die Bronzeglocke aus der Exedra des Tempelareals Sichelen I', Jahresberichte Augst und Kaiseraugst 14, 159-72

Gorbenko, A.A., and Kosyanenko, V.M. 2015: 'History of research at Asov and new ancient discoveries', Naslediye Vekov 3, 113-22 (http://heritage-magazine.com/wpcontent/uploads/2015/11/2015_3_Gorbenko_Kosyanenko.pdf)

Green, M. 1975: 'Romano-British non-ceramic model objects in South-East Britain', Archaeological Journal 132, 54-71

Gudkova, A.V. 1982: Pamiatniki rimskogo i srednevekovogo vremeni v Severo-Zapadnom Prichernomor'e: sbornik nauchnykh trudov, Kiev

Harland, H. 1891: 'Notes', Proceedings of the Society for Antiquaries of London 13, 29-30 Harnecker, J. 2008: Kalkriese 4: Die römischen Funde vom Oberesch, Mainz

Harward, C., Powers, N., and Watson, S. 2015: The upper Walbrook Valley Cemetery of Roman London, London 
Henig, M. 1978: A Corpus of Roman Engraved Gemstones from British Sites, Oxford Hills, C., and Lucy, S. 2013: Spong Hill Part IX: Chronology and Synthesis, Cambridge

Hingley, R. 1991: 'Past, present and future: the study of the Roman period in Britain', Scottish Archaeological Review 8, 90-101

Hobley, B. 1973: 'Excavations at the Lunt Roman military site, Baginton, 1968-71', Transactions of the Birmingham and Warwickshire Archaeological Society 85, 7-92

Horn, H.G. 1989: 'Ein römischer Spielturm aus Froitzheim', Bonner Jahrbücher 189, 139-60

Hosler, D. 1993: The Sound and Colour of Power: The Sacred Metallurgical Technology of Ancient West Mexico, Cambridge, MA

Hosler, D. 1995: 'Colour and meaning in the metallurgy of ancient West Mexico', World Archaeology 27, 100-15

Jelski, G. 1984: 'Pendentifs phalliques clochettes et peltae dans les tombes d'enfants de Gaule Belgique', Revue du Nord 66, 261-79

Johns, C. 1989: Sex or Symbol? Erotic Images of Greece and Rome, London Johnson, S. 1983: Burgh Castle: Excavations by Charles Green 1958-61, Gressenhall Kaufmann-Heinimann, A. 1998: Götter und Lararien aus Augusta Raurica, Augst Keily, J. 2006: 'The accessioned finds', in S. Watson with K. Heard, Development on Roman London's Western Hill, London, 92-107

Kitson Clark, M. 1935: 'A gazetteer of Roman remains in East Yorkshire', Roman Malton and District Report 5, 1-142

Kosjanenko, V.M., and Maslovskij, A.N. 2008: 'Excavations of the necropolis of the hillfort Krepostnoe in 2005-2006', Archaeological and historical investigations in Asov and the Lower Don in 2006, 331-65

Kostromichyov, D. 2016: 'Openwork buckles with pelta-form loop and opposite extension', in X. Pauli Jensen and T. Grane (eds), Imitation and Inspiration. Proceedings of the 18th International Roman Military Equipment Conference held in Copenhagen, Denmark, 9th14th June 2013, Journal of Roman military equipment Studies 17, 141-55

Künzl, E. 1993: Die Alamannenbeute aus dem Rhein bei Neupotz, Mainz 
Lethbridge, T.C. 1936: 'Further excavations at the Early Iron Age and Romano-British cemetery at Guilden Morden', Proceedings of the Cambridge Antiquarian Society 36, 109-20

Maguire, H. 1997: 'Magic and money in the early Middle Ages', Speculum 72.4, 1037-54

Manning, W.H. (ed.) 1995: Report on the Excavations at Usk, 1965-1976: The Roman Small Finds, Cardiff

Marshall, M. forthcoming, Material Culture from the Middle Walbrook Valley: Roman Small Finds, Coins, Glass and Textiles from the Bloomberg London Excavations 2010-14, London

Martens, M. 2004: 'The mithraeum in Tienen', in M. Martens and G. de Boe (eds), Roman Mithraism: The Evidence of the Small Finds, Brussels, 25-57

Martin-Kilcher, S. 2000a: 'Eine Glocke mit Votivinschrift an Deus Mercurius aus Aventicum', Bulletin de l'Association Pro Aventico 42, 135-42

Martin-Kilcher, S. 2000b: 'Mors immatura in the Roman world - a mirror of society and tradition', in Pearce et al. 2000, 63-77

Marvell, A.G., and Owen-John, H.S. 1997: Leucarum: Excavations at the Roman Auxiliary Fort at Loughor, West Glamorgan, 1982-1984 and 1987-1988, London

Milne, G., and Wardle, A. 1993: 'Early Roman development at Leadenhall Court, London, and related research', Transactions of the London and Middlesex Archaeological Society $44,23-171$

Neal, D.S. 1996: Excavations on the Roman Villa at Beadlam, Yorkshire, Leeds

Nicolay, J. 2008: Armed Batavians. Use and Significance of Weapons and Horse Gear from Non-military Contexts in the Rhine Delta (50 BC-AD 450), Amsterdam

Noll, R. 1980: 'Das Inventar des Dolichenusheiligtums von Mauer an der Url (Noricum)', Der Römische Limes in Österreich 30, 5-126

Nowakowski, W. 1988: 'Metallglocken aus der römischen Kaiserzeit im europäischen Barbaricum', Archaeologia Polona 27, 69-146

Nowakowski, W. 1994: 'Tintinnabula auf den Ostseeinseln. Die römischen Bronzeglocken in Gotland und Bornholm', Fornvännen 89, 133-43 
Nuzzo, D. 2000: ‘Amulet and grave in Late Antiquity: some examples from Roman cemeteries', in Pearce et al. 2000, 249-55

Nylén, E., Lund Hansen, U., and Manneke, P. 2005: The Havor Hoard, Stockholm

Oldenstein-Pferdehirt, B. 1984: 'Die Geschichte der Legio VIII Augusta', Jahrbuch des Römisch-Germanischen Zentralmuseums Mainz, 397-433

Ottaway, P.J., Qualmann, K.E., Rees, H., and Scobie, G.D. 2012: The Roman Suburbs and Cemeteries of Winchester, Winchester

Palmer, S.C. 1999: 'Archaeological excavations in the Arrow Valley, Warwickshire’, Birmingham and Warwickshire Archaeological Society Transactions 103, 134-42

Parker, A. forthcoming: 'The Bells! The Bells! Approaching Tintinnabula in Roman Britain and Beyond', in A. Parker and S. Mckie (eds.) Material Approaches to Roman Magic: Occult Objects and Supernatural Substances, Oxford, PAGE NUMBERS tbc

PAS: The Portable Antiquities Scheme Database: https://finds.org.uk/database (accessed $1 / 10 / 2016)$

Pearce, J., Millett, M., and Struck, M. (eds) 2000: Burial, Society and Context in the Roman World, Oxford

Pfäffli, B. 2013: Children? Children! Searching for clues in Augusta Raurica, Augst

Philp, K. 1991: The Roman Villa Site at Keston, Kent. Excavations 1968-1978, Dover

Philpott, R. 1991: Burial Practices in Roman Britain, Oxford

Picker, A. 2015: Die villa rustica von Oberndorf a. Lech, Kallmünz

Podossinov, A.V. 2002: ‘Am Rande der griechischen Oikumene', in J. Fornasier/B. Böttger (eds), Das Bosporanische Reich: der Nordosten des Schwarzen Meeres in der Antike, Mainz, 21-38

Price, E. 2000: Frocester, Stonehouse

Rees, H., Cool, H.E.M., and Crummy, N. 2008: Artefacts and Society in Roman and Medieval Winchester: Small Finds from the Suburbs and Defences, 1971-1986, Winchester

Reiß, R. 1995: 'Reiter, Pferd und Glocke im Spiegel frühmittelalterlicher Grabfunde', Acta Praehistorica et Archaeologica 25, 272-88 
Robertson, A.S. 2000 (ed. R. Hobbs and T.V. Butttrey): An Inventory of Romano-British Coin Hoards, London

Robinson, P. 2001: 'Religion in Roman Wiltshire', in P. Ellis (ed.), Roman Wiltshire and After: Papers in Honour of Ken Annable, Devizes, 147-64

Rolland, H. 1965: Bronzes antiques de haute Provence, Paris

Ross, A. 1968: 'Shafts, pits and wells - sanctuaries of the Belgic Romans?', in N.J.M. Coles and D.D.A Simpson (eds), Studies in Ancient Europe: Essays Presented to Stuart Piggott, Leicester, 255-85

Sarnowski, T. 1988: 'Das römische Heer im Norden des Schwarzen Meeres', Archeologia 38, $61-98$

Sarnowski, T. 2015: 'Black Sea', in Y. Le Bohec (ed.), The Encyclopedia of the Roman Army, Chichester, 97-8

Schlüter, W. 1993: Kalkriese: Römer im Osnabrücker Land, Bramsche

Schoenfelder, M., and Richards, J.D. 2011: 'Norse bells - a Scandinavian colonial artefact', Anglo-Saxon Studies in Archaeology and History 17, 151-68

Schuster, J. 2006: Die Buntmetallfunde der Grabung Feddersen Wierde, Oldenburg

Schuster, J. 2011: 'Springhead metalwork', in Biddulph et al. 2011, 189-291

Schuster, J., and Watson, J. 2011: 'Roman grave goods', in Biddulph et al. 2011, 276-8

Seeley, F. 1995: 'Roman doorbells', Roman Finds Group Newsletter 9, 5-6

Sherwin, G.A. 1936: ‘A Kimmeridge shale dish’, Antiquaries Journal 16, 202-3

Simonenko, A.V., Marčenko, I.I., and Limberis, N.J. 2008: Römische Importe in sarmatischen und maiotischen Gräbern zwischen unterer Donau und Kuban, Mainz

Stefani, G. 2003: Menander: la casa del Menandro di Pompei, Milan

Stoyanova, A. 2012: Child Burials in the Cemetery of Opushki, Simferopol

Stoyanova, A. 2016: 'Pendants from the cemetery of Neyzats', in I. Khrapurov (ed.), The Crimea in the Age of the Sarmatians, $200 B C-A D$ 400; 20 years of Researches at the Cemetery of Neyzats, Simferopol, 122-55

Sulimirski, T. 1970: The Sarmatians, London 
Vaday, A.H. 1985: 'Sarmatisches Gräberfeld in Törökszentmiklós-Surján-Ǔjtelep’, Acta Archaeologica Academiae Scientiarum Hungaricae 37, 345-90

Vaday, A.H., and Szőke, B.M. 1983: 'Sarmatisches Gräberfeld und gepidisches Grab in Endrőd-Szujókereszt', Communicationes Archaeologicae Hungariae 1983, 79-132

Wardle, A. 1980: 'A Roman bell from the Thames', Transactions of the London and Middlesex Archaeological Society 31, 78-80

Wardle, A. 1981: Musical Instruments in the Roman World, unpub. PhD, Institute of Archaeology, London

Webster, G. 2002: The Legionary Fortress at Wroxeter: Excavations by Graham Webster 1955-85, London

Wenham, L.P. 1968: The Romano-British Cemetery at Trentholme Drive, York, London

Wheeler, R.E.M. 1943: Maiden Castle, Dorset, London

White, R.H. 1988: Roman and Celtic Objects from Anglo-Saxon Graves: A Catalogue and an Interpretation of their Use, Oxford

Williams, D. 2007: 'Green Lane Wanborough: excavations at the Roman religious site 1999, Surrey Archaeological Collections 93, 149-269

Williams, S. 2009: Ritual Sounds in Britannia: Bronze Bells in Roman Britain, unpub. MA Dissertation, University of Reading

Wilson, P.R. 2002: Cataractonium: Roman Catterick and its Hinterland. Excavations and Research 1958-1997, Part II, York

York Museums Trust. n.d. Binnington Carr Hoard http://www.yorkmuseumstrust.org.uk/collections/search/item/?id=1643\&search_query=b GltaXQ9MTY\%3D (accessed 12/10/2015)

Zwart, A.J.M. 1998: ‘A bridled horse burial from Beuningen', Journal of Roman Military Equipment Studies 9, 77-84

\footnotetext{
${ }^{1}$ Williams 2009; while some additions were made, it was not possible to carry out a complete survey of material published since 2009.

${ }^{2}$ Aeschylus, Seven Against Thebes, lines 385-6.

${ }^{3}$ Dio Cassius, Roman History 77.12.3.

${ }^{4}$ Plutarch, Life of Aratus 7.
} 
${ }^{5}$ e.g. Neal 1996, 58; Price 2000, 67.

${ }^{6}$ Crawford 2001, 390.

${ }^{7}$ Apuleius, Golden Ass 10.46.

${ }^{8}$ Furger and Schneider 1993, fig. 9.

${ }^{9}$ Zwart 1998.

${ }^{10}$ Rei $\beta 1995$.

${ }^{11}$ Harnecker 2008, 18, pl. 45.

${ }^{12}$ Schlüter 1993, 206, fig. 11.

${ }^{13}$ Drescher 1998, 162.

${ }^{14}$ Stefani 2003, 205.

${ }^{15}$ Martial, Epigrams 14.163.

${ }^{16}$ Plutarch, Symposiacs 4.4.2.

${ }^{17}$ Caballero Zoreda 1990, No. 91.

${ }^{18}$ See below; Martin-Kilcher 2000a, 135.

${ }^{19}$ Juvenal, Satires 4, 398-456.

${ }^{20}$ Wardle 1980, 79; Wardle 1981, 355.

${ }^{21}$ e.g. Johns 1989, fig. 14; Dierichs 1999; Parker forthcoming.

${ }^{22}$ Suetonius, Life of Augustus 91.

${ }^{23}$ Williams 2009.

${ }^{24}$ Hingley 1991; Eckardt 2005.

${ }^{25}$ Bishop 1996, 8; Cowan 1992, 91; Crummy 1992, 187.

${ }^{26}$ e.g. Colchester No. 57: Crummy 1983, 51, fig. 54.1811; Frocester No. 113: Price 2000, 67, fig. 3.2.49/a;

Woodeaton No. 13: Bagnall-Smith 1999, fig. 16.1; Gayton No. 245: NMS-1BD971.

${ }^{27} \mathrm{http} / / /$ artefacts.mom.fr/fr/result.php?id=CLT-4016\&find=clochette\&pagenum=1\&affmode=vign

${ }^{28}$ No. 45: Schuster 2011, 271, fig. 119, No. 304.

${ }^{29}$ No. 312: Davies and Spratling 1976, 127, fig. 4.8.

${ }^{30}$ No. 33: A.D. $43-75 / 80$ : Cunliffe 1971, 112, fig. 46.107.

${ }^{31}$ No. 312: A.D. $50-75$ : Davies and Spratling 1976, 127, fig. 4.8.

${ }^{32}$ No. 38: A.D. 64-70: Hobley 1973, 75, fig. 24.38.

${ }^{33}$ No. 47: Manning 1995, 56, fig. 20.3.

${ }^{34}$ Nos. 63 and 93; A.D. 43-75/80: Cunliffe 1971, 112.

${ }^{35}$ No. 311; A.D. 50-75: Davies and Spratling 1976, 127, fig. 4.7.

${ }^{36}$ Nos. 80-2; A.D. 55-75: Manning 1995, 56, fig. 20.4a-c.

${ }^{37}$ No. 70; pre-A.D.75: Milne and Wardle 1993, 89, fig. 51.113.

${ }^{38}$ No. 86: Biddle 1967, 243-4, fig. 9.23.

${ }^{39}$ Hills and Lucy 2013, 91, fig. 2.29; White 1988, fig. 91.2.

${ }^{40}$ No. 98: Brailsford 1962, 2, fig. 2.A33.

${ }^{41}$ No. 84; c. A.D. 65-75/80: Anderson et al. 2001, 76-7, fig. 29.7.

${ }^{42}$ No. 310: Keily 2006, 98.

${ }^{43}$ No. 307: Booth and Cool 2006, 13.

${ }^{44}$ No. 1: Harland 1891, 29-30, Kitson Clark 1935, 65-6, Robertson 2000, 15, No. 74; York Museums Trust n.d.

${ }^{45}$ No.1: Harland 1891; No. 6: Williams, 2007.

${ }^{46}$ No. 278: Blockley et al. 1995, 1022, fig. 431.343.

${ }^{47}$ Hambleden No. 12: Cocks 1921, 195; York No. 16: Cool et al. 1995, 1539, fig. 718.6323 and Arrow Valley No. 7: Palmer 1999, 140, fig. 58.54.

${ }^{48}$ No. 308: Harward et al. 2015, 152, fig. 121.3.

${ }^{49}$ No. 17: Bishop and Dore 1988, 170, fig. 80.90.

${ }^{50}$ No. 15: Webster 2002, 117, fig. 4.15.122.

${ }^{51}$ Nos 105 Maiden Castle: Wheeler 1943, 288, fig. 97.2 and No. 106 Vindolanda: Bidwell 1985, fig. 53.93; cf. Künzl 1993, 385-6 with further references.

52 cf. Künzl 1993, 385-6; Nowakowski 1988, 120-32; Picker 2015, 144-5.

${ }^{53}$ Bourgeois 1999, 101, fig. 76.474 and 115, fig. 85.620.

${ }^{54}$ No. 103: A.D. 75-300; Evans and Metcalf 1992, 169, fig. 33.

${ }_{55}^{55}$ No. 106: A.D. 235-60; Bidwell 1985, fig. 53.93.

${ }^{56}$ No. 105: fourth century; Wheeler 1943, fig. 97.2.

${ }^{57}$ No. 113: mid-late fourth century; Price 2000, 67, fig. 3.2.49/a.

${ }^{58}$ No. 115: Anderson et al. 2001, 76-7, fig. 29.9 and No.: 313: Boon 1978, 18, fig. 2.

${ }^{59}$ No. 110: Cool 2004, 159, fig. 4.142. 
${ }^{60}$ Lion-headed studs are commonly associated with boxes in funerary contexts (e.g. Skeleton Green burials 3 and 4 (Borrill 1981, 312-21) and Springhead burial 6345 (Schuster and Watson 2011) and may have had apotropaic properties.

${ }^{61}$ Nos 282-3; Robinson 2001, 160; Wiltshire Heritage Collections, Accession numbers DZSWS:2004.240.1; DZSWS:2004.240.2.

${ }^{62}$ Anderson 1976, 32-5.

${ }^{63}$ Acc. Nos: 1917,0601.3008 and 1917,0601.3009:

http://www.britishmuseum.org/research/collection_online/collection_object_details.aspx?objectId=465947\&par

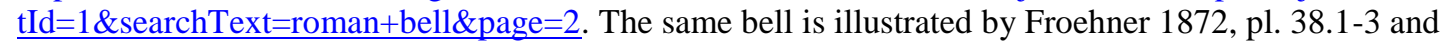

Espérandieu 1911, 344 fig. 6997.

${ }^{64}$ SF-349CD7.

${ }^{65}$ BUC-E94117.

${ }^{66}$ NMS-323DE0 and BH-9C5145.

67 SF5439.

${ }^{68}$ NMS-FB6E62 and SF-2C7AE4.

${ }^{69}$ HAMP-AF9143.

${ }^{70}$ e.g. two very similar examples with sub-triangular loops from Norfolk and Suffolk: SF-349CD7 and NMSE837B5.

${ }^{71}$ SF-2071B7 and SF-0A9956.

72 NMS-B76AC8.

${ }^{73}$ e.g. West Clandon, Surrey: SUR-B48E74.

${ }^{74}$ Casey 1986, 109, figs 15-16.

75 Schoenfelder and Richards 2011, esp. 153-4.

${ }^{76}$ We have consulted continental publications and specialists, but have not identified any parallels elsewhere; there is a bell from Ampurias, Spain, which has two cut-outs of irregular shape but those are most likely for the suspension of a clapper (http://artefacts.mom.fr/fr/home.php; CLT-4019; M. Feugère, pers. comm.).

${ }^{77}$ Keston Villa No. 19: Philp 1991, 175, fig. 54.114 and Rew Street, Isle of Wight, No. 20: Sherwin 1936, fig. 6; cf. Frere 1984, 53-5.

${ }^{78}$ Blunt 2005; Egan and Pritchard 1991, 336-41.

${ }^{79}$ Furger and Schneider 1993; Deschler-Erb 1996, 71-2, pl. 19; Flügel 1993, 99-103, pl. 33-4; Boucher et al. 1980, 84-6.

${ }^{80}$ Nowakowski 1988, 1994; Schuster 2006, 93-4.

${ }^{81}$ Nowakowski 1988.

${ }^{82}$ Flügel 1993, 99, table 3.

${ }^{83}$ Nicolay 2008, 57-8, pls 94-5.

${ }^{84}$ Furger and Schneider 1993, 164-6.

${ }^{85}$ Eckardt 2005.

${ }^{86}$ Burnham and Wacher 1990.

87 cf. Clarke 1972.

${ }^{88}$ Nos. 275, 294-306: Denison 2000.

${ }^{89}$ N. Crummy, pers. comm.

${ }^{90}$ Brindle 2014.

${ }^{91}$ Schoenfelder and Richards 2011, 153-4, fig. 2.

92 Brindle 2014.

${ }^{93}$ Simonenko et al. 2008, 322.

${ }^{94}$ Bakushev and Ilyukov 2012; Gorbenko and Kosyanenko 2015; Stoyanova 2012, fig. 8; 2016, fig. 9.

95 Nowakowski 1988, 115-18.

${ }^{96}$ Simonenko et al. 2008, 322.

97 e.g. Vaday 1985, 371; Vaday and Szőke 1983, 109-10, figs. 9 and 23; Simonenko et al. 2008, pl. 11, 32, 51, 65,70 .

98 e.g. Bekker-Nielsen 2006; Cojocaru et al. 2014; Podassinov 2002.

99 e.g. Kostromichyov 2016, figs 5 and 6.

100 cf. Eckardt 2014, 45-50, fig. 2.7.

101 Sarnowski 1988; 2015.

102 Podassinov 2002, 32.

103 Oldenstein-Pferdehirt 1984, 398-400.

${ }^{104}$ Hosler 1993; 1995, 100.

105 Dierichs 1999; 2009; Johns 1989, 67; Parker forthcoming.

106 Rolland 1965, 53-5, No. 65. 
${ }^{107}$ Kaufmann-Heinimann 1998, 241, figs 193 and 200.

${ }^{108}$ Horn 1989, 147, fig. 5.

${ }^{109}$ Erdrich 2002, 152, pl. 129.1.

${ }^{110}$ No. 32: Crummy 1992, 187, fig. 5.51.

${ }^{111}$ No. 5: Seeley 1995, 5; Ashwin and Tester 2014, 354, Nos. 104-6 and 347.

${ }^{112}$ Pfäffli 2013, 51, No. 47.

${ }^{113}$ Pfäffli 2013, 42, fig. 14.

${ }^{114}$ Biddle 1967, 245, fig. 9 .

${ }^{115} \mathrm{M}$. Marshall, pers. comm.; Marshall forthcoming.

116 cf. Booth and Cool 2006, 23; Crummy 2010, 54.

${ }^{117}$ Crummy 2010, 53-4.

${ }_{118}$ Nuzzo, 2000, 252.

${ }^{119}$ Tomb 10, Andringa and Lepetz 2013, 357-67, fig. 238; 1248, pl. 1.

${ }^{120}$ Martin-Kilcher 2000b.

${ }^{121}$ Martin-Kilcher 2000b, 73.

${ }^{122}$ Furger and Schneider 1993, 167, footnote 35; cf. Philpott 1991, 163, footnote 9; Cool 2004, 401-2; DeschlerErb 1996, 72, footnotes 540-1.

${ }^{123}$ Dasen 2015, 189, fig. 3; Dasen 2005, 181, figs. 5-6; cf. Dasen 2003; Forrer 1919, 1030.

${ }^{124}$ Jelski 1984.

${ }^{125}$ Maguire 1997, 1038-9.

${ }^{126}$ Hills and Lucy 2013, 91-2, with further references.

127 Wenham 1968 97, fig. 36.7.

${ }^{128}$ Bentley and Pritchard 1982, 149.

${ }^{129}$ Only the lid survives and it may have been placed into the grave as much for its decoration (a crouched animal) than as a functioning object (Nina Crummy, pers. comm.; cf. Biddle 1967, 242-4, fig. 9).

${ }^{130}$ Biddle 1967, 248.

${ }^{131}$ Ottaway et al. 2012, 80; Rees et al. 2008, 60, 203-4.

${ }^{132}$ Birbeck and Moore 2004, 99, fig. 8.9087.

${ }^{133}$ Booth and Cool 2006, 13.

${ }^{134}$ Harward et al. 2015, 151-2, fig. 121.

${ }^{135}$ Crummy 1983, 51, fig. 41.1610; Crummy et al. 1993, 155.

${ }^{136}$ Crummy et al. 1993 , table 2.48, 155.

${ }^{137}$ Crummy 2010, 46-7, fig. 9; Crummy 1983, 51, fig. 54.1811; Crummy et al. 1993, 41.

${ }^{138}$ Lethbridge 1936, 119, pl. Xc.

${ }^{139}$ Down and Rule 1971, 91

${ }^{140}$ Cool 2004, 159, 401-2.

${ }^{141}$ Schuster 2011, 278.

${ }_{142}$ Martin-Kilcher 2000a, 135.

${ }^{143}$ Henig 1978, 70.

${ }^{144}$ Furger and Schneider 1993; Crummy 2010, 54.

${ }^{145}$ Nos 282-3: Robinson 2001, 158-60.

${ }^{146}$ No. 6: Williams 2007, 209.

${ }^{147}$ No. 72: Wheeler 1943, 288, fig. 97, 2-3.

${ }^{148}$ No. 17: Bishop and Dore 1988, 170, fig. 80.90.

${ }^{149}$ No. 11: Evans and Hodder 2006, fig. 7.29.

${ }^{150}$ No. 13: Bagnall-Smith 1999, fig. 16.1.

${ }^{151}$ Clauss 2001.

${ }^{152}$ Boon 1960, 162, pl. XVI.

${ }^{153}$ Martens 2004, 38.

${ }^{154}$ Forrer 1919, 1030 f., after Schuster 2006, 93-4.

${ }^{155}$ Clauss 2001, 53.

${ }^{156}$ Nos 92-3: Allason-Jones and McKay 1985, 28, figs 66-7.

${ }^{157}$ Ross 1968, 270.

${ }^{158}$ No. 1: Harland 1891, 30; Robertson 2000, 15, No. 74.

${ }^{159}$ No. 27: Johnson 1983, 79.

${ }^{160}$ Davies and Spratling 1976.

${ }^{161}$ Davis and Gwilt 2008.

162 Noll 1980, 94-6, Nos 50-6.

163 Künzl 1993, 385-6; Kat J15-24. 
164 Nylén et al. 2005, 90.

165 Nylén et al. 2005, 20, fig. 10.

166 Wardle 1980.

${ }^{167}$ Schoenfelder and Richards 2011, 160. 